\title{
Dampak Pembelajaran Berbasis Masalah terhadap Kemampuan Pemecahan Masalah, Koneksi Matematis dan Kecerdasan Emosional Siswa SMP
}

\author{
Armiati $^{1)}$, Novita Anggraini ${ }^{1)}$, Sri Devi ${ }^{1)}$ \\ ${ }^{1)}$ Staf Pengajar Jurusan Matematika, FMIPA Universitas Negeri Padang \\ Email: armiati_math_unp@yahoo.co.id
}

\begin{abstract}
Problem solving ability is a skill that each student must have in mathematics learning. But the fact is, there were many students who are constrained when faced to solving mathematic problem. This situation happens due to the student's habit to imitate the teacher's answer that is given during the learning. When the student is given a different kind of problem, they were confused and not able to finish it. This papers discuss the results of problem-based learning to the problem-solving ability for the junior high school student. The study begins by designing problem-based learning devices, followed by applying of the device in learning process, then examined the impact on the problem solving ability of the junior high school student. The results showed that problem-based learning have a positive impact on the problem solving ability of junior high school student.
\end{abstract}

Keywords : Problem based learning, Problem solving, Mathematics connection, Emotional quation, Impact

This is an open access article distributed under the Creative Commons 4.0 Attribution License, which permits unrestricted use, distribution, and reproduction in any medium, provided the original work is properly cited $\odot 2018$ by author and Universitas Negeri Padang.

\section{PENDAHULUAN}

Matematika sebagai salah satu mata pelajaran wajib yang harus diajarkan di sekolah memiliki beberapa tujuan. Salah satu tujuan yang harus dicapai adalah kemampuan pemecahan masalah, karena kemampuan ini diperlukan siswa untuk bisa berhasil dalam kehidupannya. Hal ini sesuai dengan yang dikatakan oleh Bell (1978) bahwa hasil-hasil penelitian menunjukkan strategi-strategi pemecahan masalah yang umumnya dipelajari dalam pelajaran matematika, dalam hal-hal tertentu, dapat ditransfer dan diaplikasikan dalam situasi pemecahan masalah yang lain. Selain itu kemampuan siswa dalam menyelesaikan masalah secara matematis akan membantu mereka meningkatkan daya analitis dan akan memudahkan mereka menerapkan daya tersebut pada berbagai situasi. Artinya kemampuan pemecahan masalah merupakan kemampuan yang sangat penting yang harus dilatihkan dan harus dimiliki setiap siswa.

Sehubungan dengan pentingnya kemampu an pemecahan masalah dalam NCTM (2000) disebutkan bahwa memecahkan masalah bukan saja merupakan suatu sasaran belajar matematika, tetapi sekaligus merupakan alat utama untuk melakukan belajar. Karenanya kemampuan pemecahan masalah menjadi fokus pembelajaran matematika di semua jenjang pendidikan, mulai dari sekolah dasar hingga perguruan tinggi. Diharapkan dengan mempelajari pemecahan masalah melalui mata pelajaran matematika, siswa akan mendapatkan cara-cara berfikir yang efektif, kebiasaan tekun, keingintahuan yang tinggi, serta kepercayaan diri. Selanjutnya kemampuan ini dapat mereka terapkan pada situasi-situasi yang tidak biasa, seperti situasi yang akan mereka hadapi di luar ruang kelas matematika. Agar setiap siswa yang belajar matematika memiliki kemampuan pemecahan masalah matematika, maka setiap guru matematika harus dapat merancang pembelajaran yang dapat meningkatkan kemampuan tersebut. Kenyataan yang terjadi di lapangan adalah banyak siswa yang menunjukkan kemampuan pemecahan masalah yang masih rendah. Hasil penelitian yang dilakukan Daniel dkk. (2015), Memnun dkk (2012) juga menyimpulkan bahwa kemampuan pemecahan masalah masih perlu ditingkatkan karena kemampuan ini sangat diperlukan dalam kehidupan nyata.

Keberhasilan seseorang dalam menjalani kehidupan tidak hanya ditentukan oleh kemampuan pemecahan masalah secara matematis, tetapi kemampuan ini harus didukung dengan kemampuan mengelola emosi secara baik. Kemampuan mengelola emosi dikenal dengan kecerdasan emosional. Menurut Armiati 
(2010) berdasarkan definisi dari beberapa ahli, kecerdasan emosional dimaknai sebagai kecerdasan yang dapat menuntun seseorang untuk selalu mampu memotivasi diri, tidak mudah putus asa, bertindak hati-hati, menggunakan akal sehat, tidak cepat marah dan selalu dapat berempati terhadap apa yang sedang dirasakan orang-orang disekitarnya. Banyak penelitian telah membuktikan bahwa kecerdasan intelektual atau IQ hanya berperan sebesar $20 \%$ untuk kesuksesan seseorang, sementara $80 \%$ sisanya lebih ditentukan oleh kecerdasan lain termasuk kecerdasan emosional. Karenanya seorang guru dalam kegiatan pembelajaran sebaiknya juga dapat melatih siswa mengelola emosi. Pada kegiatan pembelajaran di banyak sekolah, secara umum kecerdasan emosional belum menjadi perhatian guru.

Keadaan ini tentu harus dicarikan solusinya dengan terlebih dulu mencermati penyebab rendahnya kemampuan pemecahan masalah siswa dan kurangnya perhatian guru terhadap pengembangan kecerdasan emosional siswa. Berdasarkan hasil observasi yang dilakukan saat mengunjungi praktek kependidikan di SMP dan diskusi dengan guruguru melalui kegiatan MGMP matematika SMP di Sumatera Barat, diketahui bahwa dalam mengerjakan soal siswa seringkali hanya menghapal rumus dan meniru cara pengerjaan yang diberikan guru. Akibatnya jika diberikan soal matematika yang tidak langsung diketahui rumusnya atau soal yang berbeda dari contoh yang telah dikerjakan siswa mengalami kesulitan untuk menyelesaikannya. Selain itu ketika diminta mengerjakan soal ke depan kelas sebagian besar siswa kurang percaya diri. Padahal dalam kehidupan sehari-hari mereka akan banyak menemukan masalah yang tidak ada rumusnya dan tentu sangat berbeda dari contoh dalam pembelajaran matematika. Berdasarkan hal itu dilakukan suatu penelitian yang menerapkan pembelajaran sehingga dapat melatihkan kemampuan pemecahan masalah matematis siswa, serta dapat mengembangkan kecerdasan emosional siswa.

Salah satu pembelajaran yang dapat melibatkan siswa dalam aktifitas di kelas adalah pembelajaran dengan pendekatan pemecahan masalah. Pembelajaran dengan pendekatan pemecahan masalah adalah pembelajaran yang dalam pelaksanaannya mengacu pada langkahlangkah pemecahan masalah. Langkah-langkah pemecahan masalah menurut Polya dalam bukunya How to Solve it adalah memahami masalah, merencanakan strategi pemecahan, melaksanakan rencana, dan melihat kembali hasil yang telah diperoleh. Memahami masalah dilakukan dengan cara merumuskan apa yang diketahui, apa yang ditanyakan, apakah informasi yang diperoleh cukup, kondisi/syarat apa saja yang harus terpenuhi, nyatakan atau tuliskan masalah dalam bentuk yang lebih operasional sehingga mempermudah untuk dipecahkan. Pembelajaran yang demikian identik dengan pembelajaran berbasis masalah (PBL).

Sesuai dengan langkah pemecahan masalah, dalam PBL pembelajaran diawali dengan mengorientasikan siswa pada masalah dan membimbing siswa untuk mengumpulkan informasi. Selanjutnya siswa difasilitasi untuk menemukan berbagai alternatif cara dalam menyelesaikan masalah, menentukan solusi dan terakhir mengevaluasi hasil. Tahap-tahap pada PBL ini diperkirakan dapat mengembangkan kemampuan pemecahan masalah siswa.

Menurut Arends (Hosnan, 2014) pada pembelajaran pemecahan masalah pertanyaan dan masalah yang diajukan haruslah memenuhi kriteria sebagai berikut.

a. Autentik, yaitu masalah harus lebih berakar pada kehidupan dunia nyata peserta didik.

b. Jelas, yaitu masalah dirumuskan dengan jelas, dalam arti tidak menimbulkan masalah baru yang dapat menyulitkan peserta didik.

c. Mudah dipahami, yaitu masalah yang diberikan hendaknya mudah dipahami peserta didik dan dibuat sesuai dengan tingkat perkem-bangan peserta didik.

d. Luas dan sesuai dengan tujuan pembelajaran, artinya masalah yang diberikan harus mencangkup seluruh materi pembelajaran dan sesuai dengan tujuan pem-belajaran.

e. Bermanfaat, yaitu masalah yang telah disusun dan dirumuskan haruslah bermanfaat, mening-katkan kemampuan berpikir peserta didik dan meningkatkan motivasi belajar peserta didik.

Hal ini berarti permasalahan yang dipilih dalam PBL hendaklah mengarah pada penguatan kemampuan pemecahan masalah siswa.

Beberapa penelitian yang menggunakan PBL dalam pembelajaran telah dilakukan antara lain oleh Arzu dkk (2013),dan Gorghiua dkk 
(2014). Arzu menyimpulkan bahwa PBL dapat meningkatkan kemampuan pemecahan masalah matematis siswa, sedangkan Gorghiua menemukan bahwa dengan menggunakan masalah dunia nyata sebagai kontek penting dalam PBL, siswa dapat mengembangkan kemampuan berpikir kritis dan dapat meningkatkan keterampilan pemecahan masalah mereka. Hasil penelitian-penelitian yang telah dilakukan menunjukkan bahwa dengan PBL akan dapat meningkatkan kemampuan pemecahan masalah matematis siswa. Berdasarkan hal itu penelitian yang dilakukan juga menggunakan PBL sebagai upayauntuk meningkatkan kemampuan pemecahan masalah siswa SMP.

Terkait kecerdasan emosional penelitian Armiati (2010), menyimpulkan bahwa terjadi peningkatan kecerdasan emosional mahasiswa setelah belajar dengan pembelajaran PBL, meskipun peningkatan ini masih tergolong rendah. Anita (2014) menyimpulkan dalam penelitiannya, kecemasan matematika dapat berpengaruh terhadap kemampuan koneksi matematis siswa, yaitu semakin tinggi tingkat kecemasan siswa semakin rendah kemampuan koneksi matematisnya. Namun berdasarkan pendapat Posamentier dan Stepelman (1990: 214), kecemasan itu dapat digunakan oleh pengajar untuk memberikan motivasi.

Permasalahan yang akan dijawab melalui penelitian ini adalah (1) bagaimanakah kemampuan pemecahan masalah dan kemampuan koneksi matematis siswa setelah belajar dengan pembelajaran berbasis masalah?, (2) apakah terdapat perbedaan kemampuan pemecahan masalah dan kemampuan koneksi matematis siswa yang menggunakan pembelajaran berbasis masalah dengan kemampuan pemecahan masalah dan koneksi matematis siswa yang belajar dengan pembelajaran langsung?, (3) bagaimanakah kecerdasan emosional siswa setelah belajar dengan PBL?

\section{METODE PENELITIAN}

Metode yang digunakan dalam penelitian ini adalah metode deskriptif dan eksperimen dengan rancangan acak kelompok (random block design), dimana penelitian ini dikenakan terhadap dua kelas sampel. Kelas pertama menggunakan pembelajaran berbasis masalah (PBL) dan kelas lainnya menggunakan pembelajaran langsung. Masing-masing kelas dibagi menjadi tiga kelompok, yaitu kelompok siswa berkemampuan tinggi, sedang dan rendah. Hal ini dilakukan untuk mengetahui apakah terdapat perbedaan dampak pembelajaran ditinjau dari kemampuan awal siswa terhadap kemampuan pemecahan masalah matematis siswa. Sebagai sampel adalah siswa kelas VII SMPN 3 Bukit Tinggi dan siswa kelas VIII SMPN 1 Gunuang Omeh tahun ajaran 2015/2016. Pada masing-masing tingkat dipilih secara acak, satu kelas sebagai kelas eksperimen dan satu kelas sebagai kelas control. Kelas VII terdiri dari 32 siswa untuk kelas eksperimen, dan 34 siswa untuk kelas control, sedangkan kelas VIII masing-masing kelompok terdiri dari 24 siswa.

Pada kelas VII yang dicermati adalah kemampuan pemecahan masalah. Agar dapat mengetahui kemampuan pemecahan masalah matematis siswa instrumen disusun berdasarkan materi yang diajarkan saat penelitian berlangsung, yaitu materi bangun datar segitiga dan segiempat. Instrumen yang dirancang berbentuk soal esay, sehingga melalui jawaban siswa dapat diketahui langkah pengerjaan yang dibuat siswa. Pada kelas VIII yang dicermati adalah kemampuan koneksi matematis. Untuk kecerdasan emosional diberikan angket pada semua siswa di kelas sampel, angket diberikan sebelum pelaksanaan pembelajaran dan setelah pembelajaran.

\section{HASIL DAN PEMBAHASAN}

\section{A. Kemampuan Pemecahan Masalah Matematis}

Kemampuan pemecahan masalah matematis siswa dicermati menggunakan empat indikator, yaitu kemampuan memamahami masalah, kemampuan membuat rencana penyelesaian, kemampuan menuliskan hasil dan memeriksa kembali hasil yang telah diperoleh. Perkembangan kemampuan siswa pada masingmasing indikator disajikan dalam Table 1:

Tabel l. Perkembangan Kemampuan Pemecahan Nasalah Siswa

\begin{tabular}{|l|c|c|c|c|c|c|}
\hline \multirow{2}{*}{$\begin{array}{l}\text { Indikator Pemecahan } \\
\text { Masalah }\end{array}$} & \multicolumn{5}{|c|}{ Jumlah Siswa Pada Setiap Kuis (\%) } \\
\cline { 2 - 8 } & 1 & 2 & 3 & 4 & 5 & 6 \\
\hline Memahami Masalah & 3 & 34 & 47 & 84 & 88 & 97 \\
\hline $\begin{array}{l}\text { Membuat Perencanaan } \\
\text { Penyelesaian }\end{array}$ & 0 & 15 & 75 & 82 & 84 & 88 \\
\hline Menuliskan Hasil & 75 & 80 & 84 & 87 & 88 & 97 \\
\hline Memeriksa Kembali & 0 & 16 & 31 & 60 & 57 & 66 \\
\hline
\end{tabular}

Berdasarkan Tabel 1 terlihat bahwa terdapat peningkatan kemampuan pemecahan masalah matematis siswa untuk setiap indikator. 
Pada pertemuan pertama sebagian besar siswa langsung menuliskan hasil tanpa menuliskan pemahaman terhadap masalah, rencana pe nyelesaian dan siswa juga tidak memeriksa hasil yang diperoleh. Pada pertemuan-pertemuan berikutnya terlihat ada peningkatan pada setiap indicator, dan pada pertemuan ke enam sebagian besar siswa telah menunjukkan kemampuan untuk setiap indicator pada jawabannya. Meskipun demikian dari 32 orang siswa yang mengikuti pembelajaran berbasis masalah, baru 21 orang yang telah menunjukkan kemampuan pemecahan masalah yang baik, 11 orang lainnya masih perlu terus berlatih dan mendapat perhatian dari guru.

Selanjutnya dilakukan analisis untuk mengetahui perbedaan kemampuan pemecahan masalah antara kelompok siswa yang belajar dengan PBL dan siswa yang belajar dengan pembelajaran langsung. Data yang dianalisis adalah data hasil tes kemampuan pemecahan masalah setelah perlakuan diberikan terhadap kedua kelompok sampel. Rancangan yang digunakan adalah rancangan acak kelompok, maka pertama dilakukan penyelidikan mengguna kan General Linear Model (GLM). Analisis data dilakukan dengan bantuan software MINITAB. Sebelum menggunakan GLM dilakukan uji normalitas terhadap ke dua kelompok data, dari hasil analisis diketahui bahwa data berdistribusi normal. Diketahui pula bahwa rata-rata kemampu an pemecahan masalah siswa yang belajar dengan pembelajaran berbasis masalah adalah 81, 41 sedangkan rata-rata kemampuan pemecah an masalah siswa yang belajar dengan pembelajaran langsung adalah 68,71. Terlihat bahwa kemampuan siswa pada kelompok eksperimen lebih tinggi dibandingkan kemampu an siswa kelompok control. Hasil analisis data untuk GLM disajikan pada Tabel 2

Tabel 2. Hasil Analisis GLM Kemampuan Pemecahan Masalah

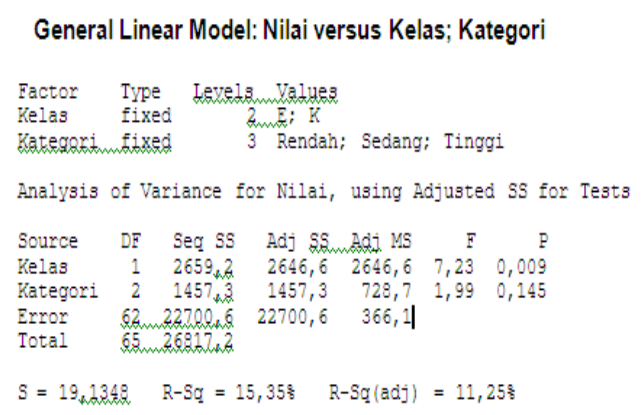

Berdasarkan hasil analisis data terlihat bahwa untuk faktor kelas nilai $\mathrm{p}$ adalah 0,009 lebih kecil dari nilai $\propto=0,05$. Artinya $\mathrm{H}_{0}$ ditolak yang bermakna terdapat perbedaan kemampuan pemecahan masalah antara siswa kelompok eksperimen dengan siswa kelompok kontrol. Berdasarkan nilai rata-rata diketahui bahwa kemampuan pemecahan masalah siswa yang belajar dengan pembelajaran berbasis masalah lebih baik dibandingkan kemampuan pemecahan masalah siswa yang belajar dengan pembelajaran langsung. Berdasarkan faktor kategori kelompok siswa ditinjau dari kemampuan awal nilai $\mathrm{p}$ adalah 0,145 lebih besar dari nilai $\propto=0,05$ yang bermakna tidak terdapat perbedaan kemampuan pemecahan masalah siswa berdasarkan kemampuan awal. Hal ini berarti penggunaan pembelajaran berbasis masalah dapat dilakukan terhadap semua kelompok siswa tanpa memperhatikan kemampuan awal.

Temuan dalam penelitian ini bersesuaian dengan hasil penelitian yang dilakukan penelitipeneliti sebelumnya (Arzu 2013, Gorghiua 2014,), bahwa pembelajaran berbasis masalah berdampak positif terhadap peningkatan kemampuan pemecahan masalah siswa. Seperti penelitian Memnun (2012) dan Daniel (2015) dalam penelitian ini juga dirasakan bahwa kemampuan pemecahan masalah siswa masih perlu terus dilatihkan agar siswa siap menghadapi berbagai tantangan dalam kehidupan yang sesungguhnya.

Untuk kemampuan koneksi matematis digunakan dua indikator, yaitu (1) kemampuan mengenali hubungan prosedur matematika suatu representasi ke prosedur representasi yang ekuivalen dan (2) kemampuan menggunakan matematika dalam area lain dan dalam kehidupan sehari-hari. Pada tabel berikut disajikan hasil analisis terkait perkembangan kemampuan koneksi matematis. Hasil ini diperoleh melalui pemberian kuis setiap akhir pembelajaran.

Tabel 2 Perkembangan Kemampuan Koneksi Watematis Siswa

\begin{tabular}{|l|c|c|c|c|c|c|}
\hline \multirow{2}{*}{ Indikator Koneksi matematis } & \multicolumn{5}{|c|}{ Jumlah Siswa pada Setiap Kuis (\%) } \\
\cline { 2 - 7 } & 1 & 2 & 3 & 4 & 5 & 6 \\
\hline $\begin{array}{l}\text { Mengenali hubungan prosedur } \\
\text { matematika suatu representasi } \\
\text { ke prosedur representasi yang } \\
\text { ekuivalen }\end{array}$ & 12 & 24 & 24 & 36 & 40 & 48 \\
\hline $\begin{array}{l}\text { Menggunakan matematika } \\
\text { dalam area lain dan dalam } \\
\text { kehidupan sehari-hani }\end{array}$ & 4 & 12 & 40 & 64 & 60 & 72 \\
\hline
\end{tabular}

Berdasarkan Tabel 2 dapat diketahui bahwa secara umum terjadi peningkatan kemampuan koneksi matematis siswa pada setiap pertemuan. Namun peresentase peningkatan kemampuan 
koneksi matematis yang terjadi masih sangat kecil. Dari tabel terlihat untuk kemampuan mengenali hubungan prosedur matematika suatu representasi ke prosedur representasi yang ekuivalen sampai pada pertemuan ke enam hanya $48 \%$ dari jumlah siswa yang menunjukkan kemampuan ini. Sedangkan untuk indikator kemampuan dalam menggunakan matematika pada area lain dan dalam kehidupan sehari-hari pada pertemuan ke enam sudah dicapai oleh sebagian besar siswa, yaitu $72 \%$. Ini berarti pembelajaran berbasis masalah dapat memudahkan siswa dalam menggunakan matematika untuk menyelesaikan masalah yang terkait dengan kehidupan sehari-hari, namun belum maksimal dalam mengembangkan kemampuan siswa dalam mengenali hubungan prosedur matematika suatu representasi ke prosedur representasi yang ekuivalen. Temuan ini juga bersesuaian dengan hasil penelitian yang dilakukan oleh Fauzi (2010), yaitu PBL belum mampu memaksimalkan peningkatkan kemampuan koneksi matematis siswa untuk indicator mencari hubungan berbagai representasi konsep dan prosedur lainnya.

Selanjutnya dilakukan analisis untuk mengetahui perbedaan kemampuan koneksi matematis siswa yang belajar dengan PBL dan kemampuan koneksi matematis siswa yang belalajar dengan PL. Analisis dilakukan dengan menggunakan General Linear Model (GLM), sebelumnya dilakukan uji normalitas dan uji homogenitas terhadap data dari ke dua kelompok sampel. Berdasarkan hasil analisis data dari ke dua kelompok sampel diketahui bahwa data berdistribusi normal dan memiliki variansi yang homogen. Melalui hasil analisis diperoleh ratarata kemampuan koneksi siswa yang belajar dengan PBL adalah 65,63 sedangkan rata-rata kemampuan koneksi siswa yang belajar dengan PL adalah 53,64. Data ini menunjukkan bahwa kemampuan koneksi siswa yang belajar dengan PBL lebih tinggi bila dibandingkan dengan kemampuan koneksi siswa yang belajar dengan PL. Hasil analisis GLM disajikan dalam gambar berikut:

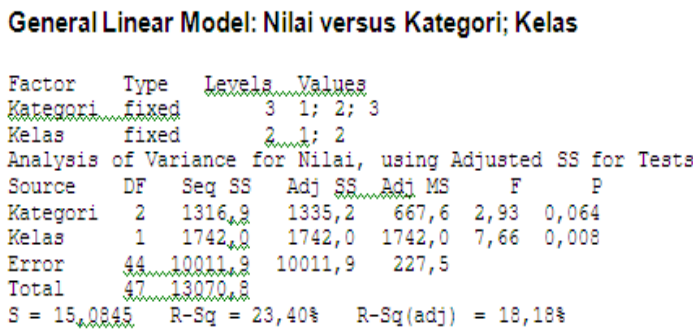

Berdasarkan hasil analisis yang disajikan pada tabel terlihat bahwa untuk kategori kemampuan awal nilai p adalah 0.064 lebih besar dari nilai $\alpha=0,05$. Hasil ini mengindikasikan bahwa terima $\mathrm{H}_{0}$, yang berarti tidak terdapat perbedaan kemampuan koneksi matematis siswa ditinjau dari kemampuan awal, artinya pembelajaran berbasis masalah dapat dilakukan pada semua kelompok siswa tanpa harus memperhatikan kemampuan awal dalam mengembangkan kemampuan koneksi matematis. Untuk level kelas yaitu kelas PBL dan kelas PL nilai $\mathrm{p}$ adalah 0,008 lebih kecil dari nilai $\alpha=0,05$, yang berarti tolak $\mathrm{H}_{0}$ yaitu terdapat perbedaan kemampuan koneksi matematis siswa berdasarkan pembelajaran. Bila dikaitkan dengan nilai rata-rata ke dua kelompok sampel maka dapat disimpulkan bahwa kemampuan koneksi matematis siswa yang belajar dengan PBL lebih baik bila dibandingkan dengan kemampuan koneksi matematis siswa yang belajar dengan PL.

Kecerdasan emosional siswa yang menjadi sampel penelitian dilihat melalui skor angket kecerdasan emosional yang diberikan sebelum pembelajaran dan sesudah pembelajaran pada semua kelompok sampel. Pada bagian berikut diberikan skor kecerdasan emosional siswa kelas VII dan kelas VIII sebelum pembelajaran dan sesuadah pembelajaran, baik dengan PBL maupun dengan PL.

\begin{tabular}{|c|c|c|c|c|c|c|c|c|}
\hline \multirow{4}{*}{$\begin{array}{c}\text { KATEGORI } \\
\text { KA }\end{array}$} & \multicolumn{8}{|c|}{ RATA-RATA SKOR KECERDASAN EMOSIONAL } \\
\hline & \multicolumn{4}{|c|}{ KELAS VII } & \multicolumn{4}{|c|}{ KELAS VIII } \\
\hline & \multicolumn{2}{|c|}{ PL } & \multicolumn{2}{|c|}{ PBL } & \multicolumn{2}{|c|}{ PL } & \multicolumn{2}{|c|}{ PBL } \\
\hline & AWAL & AKHIR & AWAI & AKHIR & AWAL & AKHIR & AWAL & AKHIR \\
\hline TINGGI & 181,63 & 174,87 & 180 & 196,25 & 194,4 & 196,4 & 189,67 & 199,5 \\
\hline SEDANG & 191,24 & 180,19 & 178 & 192 & 178,61 & 184,61 & 182,63 & 201,36 \\
\hline RENDAH & 189,33 & 174,67 & 188 & 1959 & 175,66 & 194,67 & 182 & 192 \\
\hline TOTAL & 188,94 & 179,16 & 181,3 & 193,87 & 181 & 189,58 & 184,13 & 197,46 \\
\hline
\end{tabular}

Berdasarkan data yang disajikan pada Tabel 3 di atas terlihat untuk kelas VII skor kecerdasan emosional siswa pada kelompok PL sebelum pembelajaran lebih tinggi dibandingkan dengan skor kecerdasan emosional setelah 
pembelajaran untuk setiap kategori kemampuan awal dan juga untuk keseluruhan (total). Sedangkan pada kelompok PBL skor kecerdasan emosional siswa sebelum pembelajaran lebih rendah dibandingkan dengan skor kecerdasan emosional siswa setelah pembelajaran. Artinya terdapat peningkatan skor kecerdasan emosional siswa setelah pembelajaran dengan PBL. Namun bila dikaitkan dengan skor ideal, kecerdasan emosional siswa pada kedua pembelajaran masih terkategori rendah $(60 \% \leq$ skor $<70 \%)$.

Untuk kelas VIII terlihat bahwa ada peningkatan skor kecerdasan emosional siswa pada ke dua kelompok (PL dan PBL). Bila dicermati rata-rata peningkatan skor kecerdasan emosional siswa pada PBL lebih tinggi dibandingkan dengan rata-rata peningkatan skor kecerdasan emosional siswa pada PL. Sama halnya dengan kelas VII, meskipun terdapat peningkatan rata-rata skor kecerdasan emosional siswa, tetapi kecerdasan emosional siswa kelas VIII masih terkategori rendah, berada pada rentang $60 \% \leq$ skor $<70 \%$. Bila dicermati lebih lanjut pada kedua kelompok sampel yang belajar dengan PBL, peningkatan rata-rata skor kecerdasan emosional hanya berkisar antara 10 sampai 19 poin.

\section{KESIMPULAN}

Berdasarkan hasil penelitian dapat disimpulkan bahwa:

1) Kemampuan pemecahan masalah siswa pada awal penelitian masih kurang baik, sebagian besar siswa langsung memberikan hasil tanpa menuliskan informasi dari masalah yang akan diselesaikan tidak menuliskan rencana penyelesaian, dan siswa juga tidak melakukan pengecekan kembali terhadap hasil yang telah diperolehnya. Setelah diberikan pembelajaran berbasis masalah kemampuan siswa dalam memecahkan masalah semakin baik, sebagian besar siswa menuliskan informasi, membuat rencana dan melakukan pemeriksaan kembali.

2) Kemampuan pemecahan siswa yang belajar dengan pembelajaran berbasis masalah lebih baik bila dibandingkan dengan kemampuan pemecahan masalaha siswa yang belajar dengan pembelajaran langsung.

3) Pembelajaran berbasis masalah dapat meningkatkan kemampuan koneksi matematis siswa. Melalui pelitian ini juga diketahui bahwa pembelajaran berbasis masalah dapat memudahkan siswa dalam menggunakan matematika untuk menyelesaikan masalah yang terkait dengan kehidupan sehari-hari, namun belum maksimal mengembangkan kemampuan siswa dalam mengenali hubungan prosedur matematika suatu representasi ke prosedur representasi yang ekuivalen.

4) Kemampuan koneksi matematis siswa yang belajar dengan PBL lebih baik bila dibandingkan dengan kemampuan koneksi matematis siswa yang belajar dengan pembelajaran langsung.

5) Secara umum pembelajaran berbasis masalah dapat meningkatan kecerdasan emosional siswa, baik di kelas VII maupun di kelas VIII. Namun kecerdasan emosional siswa untuk ke dua kelompok sampel yang belajar dengan pembelajaran berbasis masalah masih terkategori rendah.

Dari temuan ini disarankan agar guru di sekolah dapat menggunakan pembelajaran berbasis masalah dalam proses pembelajarannya, karena kemampuan pemecahan masalah merupakan kemampuan yang sangat esensial yang diperlukan oleh setiap siswa dalam kehidupan sesungguhnya.

\section{DAFTAR PUSTAKA}

Anita, Ika Wahyu. (2014). Pengaruh Kecemasan Matematika (Mathematics Anxiety) terhadap Kemampuan Koneksi Matematis Siswa SMP. Jurnal Ilmiah Infinity, STKIP Siliwangi Bandung, Vol. 3 No. 1, Februari 2014

Ar1*, a ,A. Arzu. Katrancib, Yasemin. (2014). The opinions of primary mathematics student-teachers on problem based learning method. World Conference on Educational Sciences - WCES 2013

Armiati. (2010). Pengembangan Perangkat Pembelajaran Berdasarkan Model Problem Base untuk Menumbuhkan Kemampuan Komunikasi Matematis dan Kecerdasan Emosional Mahasiswa, Laporan Penelitian Hibah Disertasi Program Doktor, UPI bandung.

Bell, F. H. (1978). Teaching and Learning Mathematics. USA: Wm.C. Brown Company Publishers.

Damirel, Melek. Derman, Ipek. Karagedik, Edibe. (2015). A Study on the Relationship between Reflective Thingking Skill toward 
Problem Solving and Attitudes to Mathematics. Procedia, Social and Behavioral Sciences 197 (2015) 2086 2096. $7^{\text {th }}$ Word Conference on Educational, Sciences (WCES- 2015) 0507 February 2015 Novotel Athens Convention Center, Athens Gree. Elsevier Fauzi, Amin (2011). Peningkatan Kemampuan Koneksi Matematis dan Kemandirian Belajar Siswa dengan Pendekatan Pembelajaran Metakognitif di SMP. Proceeding International Seminar and the Fourth National Conference on Mathematics Education 2011. ISBN: 978979-16353-7-0, P-11

Gorghiua*, Gabriel. Drăghicescub, Luminiţa Mihaela. Cristeac, Sorin. Petrescub, AnaMaria. Gorghiud, Laura Monica. (2014). Problem-Based Learning - An Efficient Learning Strategy in The Science Lessons Context. World Conference on Educational Sciences- WCES 2014

Hosnan, M. 2014. Pendekatan Saintifik dan Kontekstual dalam pembelajaran Abad 21:
Kunci Sukses Implementasi Kurikulum 2013. Bogor: Ghalia Indonesia.

Memnun, Dilek Sezgin. Hart, Lynn C. Recai Akkaya. (2012). A Research on the Mathematical Problem-Solving Beliefs of Mathematics, Science and Elementary PreService Teachers in Turkey in terms of Different Variables. International Journal of Humanities and Social Science Vol. 2 No. 24 [Special Issue - December 2012]

National Council of Teacher of Mathematic. 2000. Principles and Standards for School Mathematics. Reston, VA: Author.

Tan, Oon-Seng. (2004). Enhancing Thingking through Problem-Based Learning Approaches. Singapura: Thomson Learning

Kemdikbud. (2014). Peraturan Menteri Pendidikan dan Kebudayaan Nomor 103 tahun 2014 tentang Pembelajaran padaPendidikan Dasar dan Pendidikan Menengah. Jakarta: Kemdikbud. 